\title{
Variability in the recognition of distinctive immunofluorescence patterns in different brands of HEp-2 cell slides
}

\author{
Variabilidade no reconhecimento de padrões de imunofluorescência \\ indireta em diferentes marcas de lâminas HEp-2
}

Alessandra Dellavance'; Wilson de Melo Cruvinel²; Paulo Luiz Carvalho Francescantonio33; Cristovão Luis Pitangueira Mangueira; Inês Cristina Drugowick ${ }^{5}$ Silvia Helena Rodrigues ${ }^{6}$; Luis Eduardo Coelho Andrade ${ }^{7}$

\begin{abstract}
Introduction: Indirect immunofluorescence on HEp-2 cells is considered the gold standard for the detection of autoantibodies against cellular antigens. However, the culture conditions, cell fixation and permeabilization processes interfere directly in the preservation and spatial distribution of antigens. Therefore, one can assume that certain peculiarities in the processing of cellular substrate may affect the recognition of indirect immunofluorescence patterns associated with several autoantibodies. Objective: To evaluate a panel of serum samples representing nuclear, nucleolar, cytoplasmic, mitotic apparatus, and chromosome plate patterns on HEp-2 cell substrates from different suppliers. Materials and methods: Seven blinded observers, independent from the three selected reference centers, evaluated 17 samples yielding different nuclear, nucleolar, cytoplasmic and mitotic apparatus patterns on HEp-2 cell slides from eight different brands. The slides were coded to maintain confidentiality of both brands and participating centers. Results: The 17 HEp-2 cell patterns were identified on most substrates. Nonetheless, some slides showed deficit in the expression of several patterns: nuclear coarse speckled/U1ribonucleoprotein associated with antibodies against RNP (U1RNP), centromeric protein F (CENP-F), proliferating cell nuclear antigen (PCNA), cytoplasmic fine speckled associated with anti-Jo-1 antibodies (histidyl synthetase), nuclear mitotic apparatus protein 1 (NuMA-1) and nuclear mitotic apparatus protein 2 (NuMA-2). Conclusion: Despite the overall good quality of the assessed HEp-2 substrates, there was considerable inconsistency in results among different commercial substrates. The variations may be due to the evaluated batches, hence generalizations cannot be made as to the respective brands. It is recommended that each new batch or new brand be tested with a panel of reference sera representing the various patterns.
\end{abstract}

Key words: antinuclear antibodies; autoantibodies; immunofluorescence pattern; indirect immunofluorescence.

\section{INTRODUCTION}

The screening of autoantibodies against cellular antigens, antinuclear antibodies (ANA), is a test developed to aid in the diagnosis of patients with suspected autoimmune diseases. It is performed through indirect immunofluorescence (IIF) on tumor cells derived from human larynx carcinoma (HEp-2 American Type Culture Collection [ATCC] CCL-23), a continuous tumor cell lineage, hence its designation (ANA-HEp-2). It has fully replaced the use of animal tissue as antigen substrate due

First submission on 28/10/12; last submission on 28/12/12; accepted for publication on 28/12/12; published on 20/06/13

1. Doctor in Health Sciences by Escola Paulista de Medicina da Universidade Federal de São Paulo (EPM-UNIFESP); scientific advisor at Grupo Fleury-Research and Development Department; associate researcher in Rheumatology at UNIFESP.

2. Doctor in Health Sciences by EPM-UNIFESP; director of the Biomedicine and Pharmacy Department at Pontifícia Universidade Católica (PUC-Goiás).

3. Master's in Environmental and Health Sciences by PUC-Goiás; director of the Medicine Department at PUC-Goiás; scientific director of Padrão Laboratório Clínico.

4. Doctor in Pathology by Faculdade de Medicina da Universidade de São Paulo (FMUSP); chief of the Immunology Section, Division of Laboratories (LIM 03) at Hospital das

Clínicas (HC) at FMUSP; medical manager at Hospital Israelita Albert Einstein-Clinical Pathology Department.

5. Biomedical scientist; technical coordinator of the Immunopathology Sector at Hospital Israelita Albert Einstein-Clinical Pathology Department.

6. Master's in Health Sciences by EPM-UNISFESP; biomedical scientist at UNIFESP Immuno-Rheumatology Laboratory.

7. Doctor in Medicine by EPM/UNIFESP; associate professor/lecturer in Rheumatology at UNIFESP; medical assistant at Grupo Fleury-Immunology Department. 
to multiple factors, among which stands out the possibility of a myriad of human autoantigens in a wide spatial arrangement and enriched by the representation of various cell cycle stages. These characteristics allow an excellent visualization of the spatial distribution of autoantigens, resulting in the identification of multiple IIF patterns. The representation of cells at different stages of cell division promotes detection of autoantibodies against a wide variety of autoantigens expressed in mitosis and interphase (phases G0, G1, G2 and S). Moreover, they feature multiple nucleoli and cytoplasm rich in organelles and cytoplasmic proteins ${ }^{(3,5)}$. Due to these characteristics, autoantibody screening against cellular components through IIF using HEp-2 cells as antigen substrate is currently recommended as the gold standard by the American College of Rheumatology ${ }^{(13)}$.

One of the benefits of ANA-HEp-2 method also comprises a hindrance in this test, that is to say that its extreme sensitivity leads to positive results in some individuals without evidence of systemic autoimmune disease. In fact, national and international studies estimate a frequency of approximately $13 \%$ positive results and titer of $1 / 80$ in the general population ${ }^{(11,17)}$. This scenario becomes even more problematic in view of the widespread use of this test. Previously, antinuclear antibody screening was requested mostly by nephrologists and rheumatologists, specialists who commonly treat patients with systemic lupus erythematosus (SLE), systemic sclerosis and other systemic autoimmune diseases. Currently, many experts such as dermatologists, gastroenterologists, gynecologists, orthopedic surgeons, otolaryngologists, neurologists and psychiatrists have included it in their laboratory screenings. Considering the fact that a minority of patients assisted at these clinics will develop systemic autoimmune disease, there is a scenario of low pre-test probability for these syndromes. The result is a high frequency of positive results in unexpected clinical settings, affecting the positive predictive value of ANA-HEp-2. Accordingly, it is important to highlight that the yielded results should be considered and interpreted cautiously.

One of the ways that may assist in the correct interpretation of a positive ANA-HEp-2 result is the careful analysis of IIF pattern. In fact, in recent years the relevance of IIF on ANA-HEp-2 interpretation has been consistently emphasized ${ }^{(11)}$. The observed pattern may provide preliminary information on the nature of the autoantibody in a given sample and even indicate which additional and specific tests should be conducted. Some examples are the following: nuclear speckled pattern, which suggests the presence of anti-Sm and/or anti-U1RNP(14); nucleolar pattern with perichromosome plate, which indicates anti fibrillarin antibodies ${ }^{(12)}$; cytoplasmic dense fine speckled pattern, often associated with the presence of ribosomal P protein antibodies ${ }^{(9)}$; centromeric nuclear pattern, which results from the identification of centromere proteins $(\mathrm{CENPS})^{(6)}$; nuclear type and fine speckled nucleolar with cytoplasmic staining and presence of fluorescent spots on the chromosome plate (mixed pattern), which is strongly associated with the presence of deoxyribonucleic acid (DNA) topoisomerase 1 antibodies ${ }^{(4)}$.

Successive methodological improvements, namely the quality of secondary antibody and overall microscope resolution, have resulted in a significant increase in assay sensitivity, hence unexpected positive results have commonly been observed ${ }^{(11,17)}$. Furthermore, several companies have started to produce commercial kits for ANA-HEp-2, resulting in its widespread use worldwide ${ }^{(7)}$. However, cell culture conditions and slide preparation are restricted to protocols adapted by manufacturers and whose technical features sometimes are not shared with users. This is relevant, since the availability of epitopes and spatial distribution of autoantigens may undergo considerable changes as a result of culture conditions and cell fixation. Consequently, the same serum in slides from different suppliers may result in distinctive IIF patterns due to differences in the expression of nuclear, nucleolar, cytoplasmic autoantigens and chromosome plate (Figure 1).

Given the relevance of IIF pattern characterization and classification and the fact that the manufacturing process of HEp-2 cells slides have potential influence on antigen distribution and epitope availability, it is vital to identify how sensitive the various IIF patterns are in relation to specific preparations of antigenic substrate. Therefore, the objective of this study was to evaluate a panel of IIF patterns on HEp-2 cells from different origins.

\section{MATERIALS AND METHODS}

\section{Serum samples}

A panel of human serum samples (Table 1) was selected from the autoantibody serum bank at Fleury Medicina e Saúde - Research and Development Department (R\&D) to represent the most relevant IIF patterns on HEp-2 and also acknowledged by the Brazilian Consensus for autoantibodies on HEp- $2^{(2)}$. The samples were sequentially numbered so that it was not possible to identify its immunological specificity (Table 2). Accordingly, all readings were conducted blindly. The samples were kept in a freezer $\left(-80^{\circ} \mathrm{C}\right)$ until test performance. A complete set of this sample panel was distributed to seven independent observers from three centers of excellence in autoantibodies: Pontifícia Universidade Católica Clinical Laboratory (PUC-Goiás), Hospital Albert Einstein Immunology Laboratory and Group Fleury, Immunology and R\&D Departments. To ensure data confidentiality, the three centers 

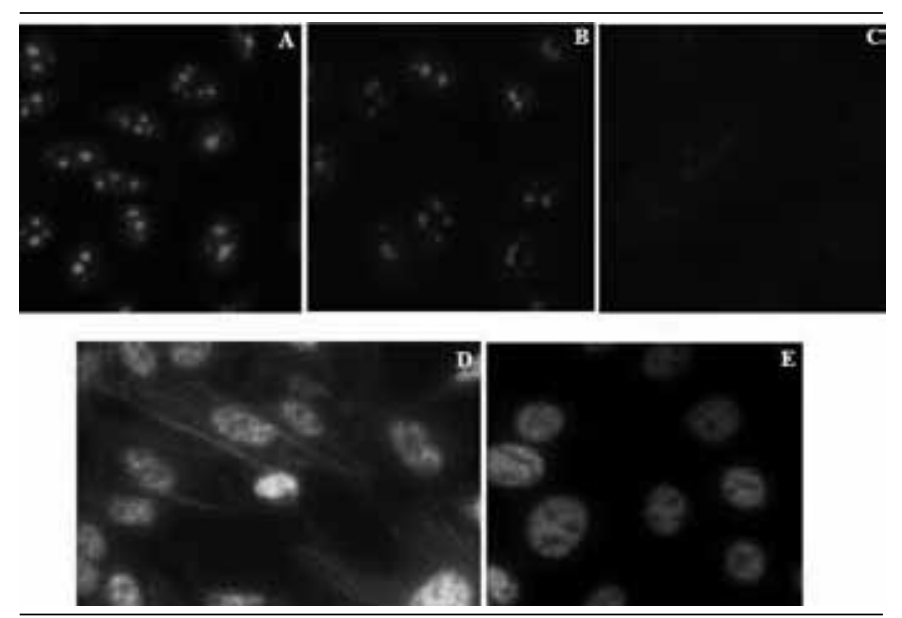

FIGURE 1 - IIF on HEp-2 cells

A-C: serum sample from patient with scleroderma and with nucleolar pattern (titer $\geq$ 1/640) processed on three substrates from different commercial brands; D-E: serum sample from patient with anti-U1 RNP antibodies and anti-actin processed on substrates from two different suppliers.

IIF: indirect immunofluorescence; RNP: ribonucleoprotein.

were randomly designated as centers $\mathrm{A}, \mathrm{B}$ and $\mathrm{C}$. The readings in each center were harmonized, creating a single consolidated report.

\section{Antigenic substrate - Hep-2 cells}

The study included seven brands of commercial kits for HEp-2 autoantibodies, which met basic quality criteria as to cell density, number of mitosis per field, cell morphology and quality of the conjugates. Furthermore, they were in accordance with the sale regulations proposed by the National Agency of Sanitary Surveillance (ANVISA). All commercial kits were kindly provided by the suppliers named herein in alphabetical order: (1) Bion Interpreise, Inc. (batch NA-3642 - Reference AN - 1012); (2) Medizinische Euroimmun Labordiagnostika AG (batch F090806D6 - Code FA 1520-0405); (3) Hemagen Diagnostic Inc. (Virgo batch 4149 - code 902345); (4) IMMCO Diagnostics (batch 905197 - code 1102-60); (5) Immunoconcepts HEp2000 ANA-Ro Test System (batch 0820403 - reference AS 2014 -Ro); (6) Inova Diagnostics, Inc. (batch 870364 - code 708100); and (7) Viro-Immun Labor-Diagnostika GmbH (batch AHEPK 06d-09 reference IFG109). They were carefully identified with numerals in order to maintain confidentiality. Moreover, we counted eight HEp-2 slides prepared at UNIFESP Immuno-Rheumatology Laboratory (Universidade Federal de São Paulo-Escola Paulista de Medicina [UNIFESP-EPM]). For the preparation of these slides, HEp-2 cells were cultured in Dulbecco modified eagle's medium (DMEM) with 10\% fetal bovine serum (Gibco Invitrogen Life Technologies) and incubated at $5 \% \mathrm{CO}_{2}$ and $37^{\circ} \mathrm{C}$ until they
TABLE 1 - Description of ANA-HEp-2 patterns distributed to the participating centers

\begin{tabular}{ll}
\hline \multicolumn{1}{c}{ IIF pattern } & Abbreviation \\
\hline Homogeneous speckled & \\
Coarse speckled & Ho \\
Coarse speckled type reticulated & CS \\
Dense fine speckled & CSTR \\
Quasi-homogeneous & DFS \\
Centromeric & QH \\
Fine speckled and mitotic apparatus & C \\
Fine speckled and rare nuclear dots & NuMA-1 \\
Multiple nuclear dots & FS RND \\
PCNA & MND \\
CENP-F & PCNA \\
\hline & CENP-F \\
\hline Homogeneous nucleolar & Nucleolar patterns \\
Nucleolar clumpy & HoNu \\
Fine speckled + nucleolar speckled + NOR & NuP \\
\hline & RNA pol \\
\hline Dense fine speckled & Ctto DFS \\
\hline
\end{tabular}

\begin{tabular}{lll}
\hline \multicolumn{3}{c}{ Metaphase chromosome plate } \\
\hline Mitotic spindles & NuMA-2 \\
\hline
\end{tabular}

ANA-HED-2: antinuclear antibodies HEp-2; IIF: indirect immunofluorescence; PCNA: proliferating cell nuclear antigen; CENP-F: centromeric protein F; NOR: nucleolar organizing region; RNA: ribonucleic acid.

became subconfluent. Subsequently, the cells were trypsinized and reseeded directly on glass slides with circles delimited by hydrophobic mask. After 24 hours of growth under the same conditions, the culture medium was withdrawn and the slides washed in PBS (Phosphate Buffered Saline - sodium phosphate $10 \mathrm{mmol} / 1, \mathrm{NaCl}, 0.15 \mathrm{~mol} / \mathrm{l}, \mathrm{pH} 7.2$ to 7.4 ). After removing excess PBS, the cells were immediately fixed in methanol at $-20^{\circ} \mathrm{C}$ for 8 minutes and permeabilized in acetone at $-20^{\circ} \mathrm{C}$ for 2 minutes. After drying at room temperature, the slides were wrapped in aluminum foil and cling film and stored at $-70^{\circ} \mathrm{C}$ until use.

Each central processor received the serum samples and ANA-HEp-2 mini-kits from each of the suppliers mentioned above, including conjugates and appropriate solutions. The 
TABLE 2 - Interpretation results of IIF patterns on ANA-HEp-2 from each participating center

\begin{tabular}{|c|c|c|c|c|c|c|c|c|}
\hline \multirow[t]{2}{*}{ Antibody patterns on ANA-HEp-2 } & \multicolumn{8}{|c|}{ Commercial substrates $^{1}$} \\
\hline & 1 & 2 & 3 & 4 & 5 & 6 & 7 & 8 \\
\hline Ho & $+++^{2}$ & +++ & +++ & +++ & +++ & +++ & +++ & +++ \\
\hline CS & +++ & +++ & +++ & +++ & +++ & +++ & +++ & $\Theta \Theta \Theta$ \\
\hline CSTR & +++ & +++ & +++ & +++ & +++ & +++ & +++ & +++ \\
\hline DFS & +++ & +++ & +++ & +++ & +++ & +++ & +++ & +++ \\
\hline $\mathrm{QH}$ & $++\Theta$ & $++\Theta$ & $++\Theta$ & $++\Theta$ & $++\Theta$ & $++\Theta$ & $++\Theta$ & $++\Theta$ \\
\hline C & +++ & +++ & +++ & +++ & +++ & +++ & +++ & +++ \\
\hline NuMA-1 & $++\Theta$ & $++\Theta$ & $++\Theta$ & $++\Theta$ & $++\Theta$ & $++\Theta$ & $++\Theta$ & $\Theta \Theta \Theta$ \\
\hline FS RND & +++ & +++ & +++ & +++ & +++ & +++ & $\Theta \Theta \Theta$ & +++ \\
\hline MND & $++\Theta$ & ++0 & +++ & +++ & +++ & +++ & +++ & +++ \\
\hline PCNA & +++ & $\Theta \Theta \Theta$ & $\Theta \Theta \Theta$ & +++ & $\Theta \Theta \Theta$ & $\Theta \Theta \Theta$ & $\Theta \Theta \Theta$ & $\Theta \Theta \Theta$ \\
\hline CENP-F & $++\Theta$ & $\Theta \Theta \Theta$ & $\Theta \Theta \Theta$ & $\Theta \Theta \Theta$ & $\Theta \Theta \Theta$ & $\Theta \Theta \Theta$ & ++0 & $\Theta \Theta \Theta$ \\
\hline $\mathrm{HoNu}$ & +++ & +++ & +++ & +++ & +++ & +++ & +++ & +++ \\
\hline $\mathrm{NuP}$ & +++ & +++ & +++ & +++ & +++ & +++ & +++ & +++ \\
\hline RNA pol & +++ & +++ & +++ & +++ & +++ & +++ & +++ & +++ \\
\hline Cyto FS & +++ & $\Theta \Theta \Theta$ & $\Theta \Theta \Theta$ & $\Theta \Theta \Theta$ & $\Theta \Theta \Theta$ & +++ & $\Theta \Theta \Theta$ & $\Theta \Theta \Theta$ \\
\hline Cyto DFS & $++\Theta$ & $++\Theta$ & ++0 & ++0 & ++0 & ++0 & ++0 & ++0 \\
\hline NuMA-2 & +++ & +++ & +++ & +++ & +++ & +++ & +++ & $\Theta \Theta \Theta$ \\
\hline
\end{tabular}

Ho: homogeneous speckled; CS: coarse speckled; CSTR: coarse speckled type reticulated; DFS: dense fine speckled; OH: quasi-homogeneous; C: centromeric; NuMA-1: fine speckled and mitotic apparatus; FS RND: fine speckled and rare nuclear dots; MND: multiple nuclear dots; PCNA: proliferating cell nuclear antigen; CENP-F: centromeric protein F; HoNu: bomogenous nucleolar; NuP: nucleolar clumpy; RNA pol: fine speckled + nucleolar speckled + NOR; Cyto FS: fine speckled; Cyto DFS: dense fine speckled; NuMA-2: mitotic spindles; NOR: nucleolar organizing region.

1: numbers 1 to 8 represent the different substrate brands included in this study; 2: symbols + and $\Theta$ indicate the centers that identified or not, respectively, the different patterns on the surveyed substrates.

centers were advised to strictly follow the technical procedures for performing IIF in accordance with the technical instructions from each manufacturer. They were also instructed to avoid visual identification under microscope analysis.

\section{IIF on in house slides}

For the reaction of IFI with the substrate prepared by UNIFESP-EPM Immuno-Rheumatology Department, $20 \mu \mathrm{l}$ of serum were diluted at $1 / 80 \mathrm{PBS}$. Slides with HEp-2 cells were incubated for $30 \pm 5$ minutes in a humid chamber at $37^{\circ} \mathrm{C}$. Subsequently, two 10-minute washes were performed with PBS. The fluorescent conjugate contained sheep immunoglobulins against human immunoglobulin class $\mathrm{G}$ ( $\operatorname{Ig} G$ ) stained with fluorescein isothiocyanate (fluorescein isothiocyanate conjugate [FITC] - Fluoline ${ }^{\circledR}$ G bioMérieux SA, Code 75692, Marcy l'Etoile, France) and diluted in Evans blue solution (10 mg Evans Blue in $100 \mathrm{ml} \mathrm{PBS}$ ) at 1/200. This conjugate was applied into each well and incubated for $30 \pm 5$ minutes in a humid chamber at $37^{\circ} \mathrm{C}$. This was followed by two 10 -minute wash cycles with PBS and microscope slide mounting with 70\% PBS glycerol and coverslip. IIF reaction on commercial slides was performed in strict accordance with the recommendations of each supplier.

All slide readings were conducted blindly so that the examiner was unaware of the sample origin and slide manufacturer. The three centers employed epifluorescence microscope with mercury lamp and there were the following specific features in each center: center A used an Olympus BX-50 fluorescence microscope with Ushio mercury lamp under $400 \times$ magnification; center B used a Leica DMLB fluorescence microscope with a 100 watt mercury vapor lamp under 1,000× magnification; center $\mathrm{C}$ used a Nikon Eclipse E600W microscope with HB0 mercury lamp under 400× magnification.

The images were captured by an Olympus QColor 3 camera using QCapture program. Image-J and Image-Pro Plus 5.1 programs were applied for image analysis. 


\section{Strategy for evaluating results}

The readings were recorded individually in standardized forms and sent to the coordinating center for data compilation in a central spreadsheet, which included concordance formulas for result assessment. For this analysis, it was deemed that the purpose of this study was to determine the degree of reproducibility of different patterns in different commercial substrates and through readings conducted by different specialists. Since the actual ANAHEp-2 test reading contains a considerable degree of subjectivity, we considered reproducible those patterns that were identified by at least two participating centers (Figure 2).

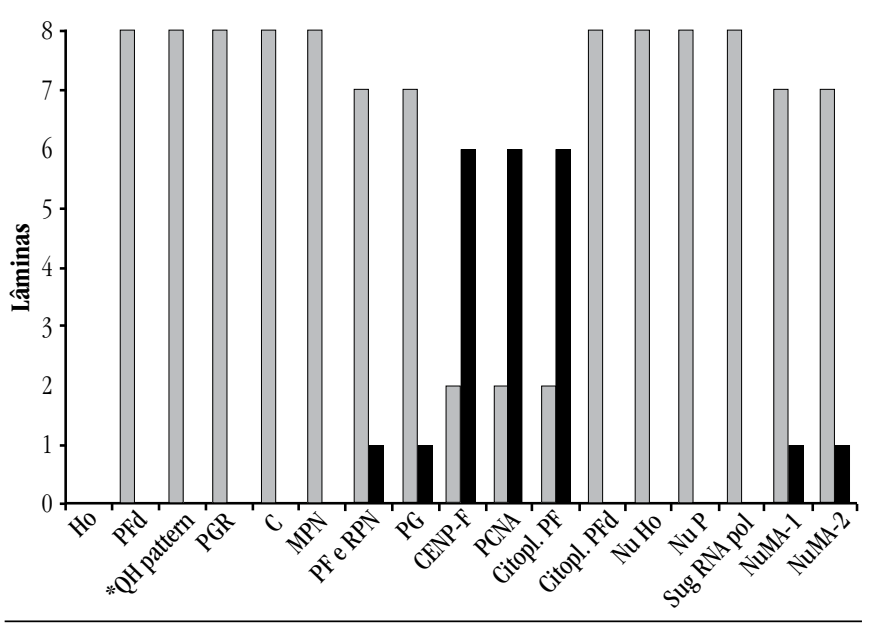

FIGURE 2 - Characterization ability of 17 autoantibody patterns on HEp-2 cells by eight different slides (seven commercial and one in house)

The grey columns indicate the reading concordance within different slides and the black columns suggest inability to identify them.

${ }^{*} \mathrm{QH}$ nuclear quasi-homogeneous speckled pattern: center C identified the pattern as dense fine speckled on the first five slides and as bomogeneous nuclear in the last three slides.

Ho: homogeneous speckled; DFS: dense fine speckled; QH: quasi-homogeneous speckled*; CSTR: coarse speckled type reticulated; C: centromeric; MND: multiple nuclear dots; FS RND: fine speckled and rare nuclear dots; CS: coarse speckled; CENP-F: centromeric protein F; PCNA: proliferating cell nuclear antigen; Cyto FS: fine speckled; Cyto DFS: dense fine speckled; Nu Ho: nucleolar homogeneous; Nu P: nucleolar clumpy; RNA pol: fine speckled + nucleolar speckled + nucleolar organizing region; NuMA-1: fine speckled and mitotic apparatus; NuMA-2: mitotic spindles.

\section{RESULTS}

Seventeen IIF patterns were properly identified by the readers from the three centers in most commercial HEp-2 cell substrates. For data compilation, the reading was considered consistent when two out of three participating centers reported the same result (Figure 2). In general, eight tested substrates showed good reproducibility of all seventeen IIF patterns. However, some patterns exhibited some variability in some substrate identifications (Figure 2). The nuclear patterns that were reproduced in the eight assessed brands of HEp-2 slides were the following: homogeneous (sample with anti-native DNA), dense fine speckled (sample with anti-LEDGF/p75 antibodies [lens epithelium-derived growth factor]), quasi-homogeneous, coarse speckled type reticulated, centromeric, and multiple nuclear dots (sample with anti-Sp-100).

The nuclear fine speckled and the rare nuclear dot patterns were reproduced in $7 / 8$ (87.5\%) slide brands. In slide $\mathrm{G}$, it was possible to observe only the nuclear fine speckled pattern. To view the nuclear coarse speckled pattern, we used a sample with anti-U1 RNP autoantibodies (ribonucleoprotein U1). Slide H showed nuclear fine speckled pattern with a slight difference in intensity among nuclei from cells in interphase. It was possible to identify the coarse speckled pattern (Figure 3) in the remaining slides. The nuclear pattern associated with antibodies against CENP-F (centromeric protein F) was identified only in slides A and $\mathrm{G}$, whereas the nuclear fine speckled pattern was observed in the others (Figure 4). The nuclear pattern associated with antibodies against PCNA was observed only in slides A and D, whereas the nuclear fine speckled pattern was identified in the others (Figure 5).
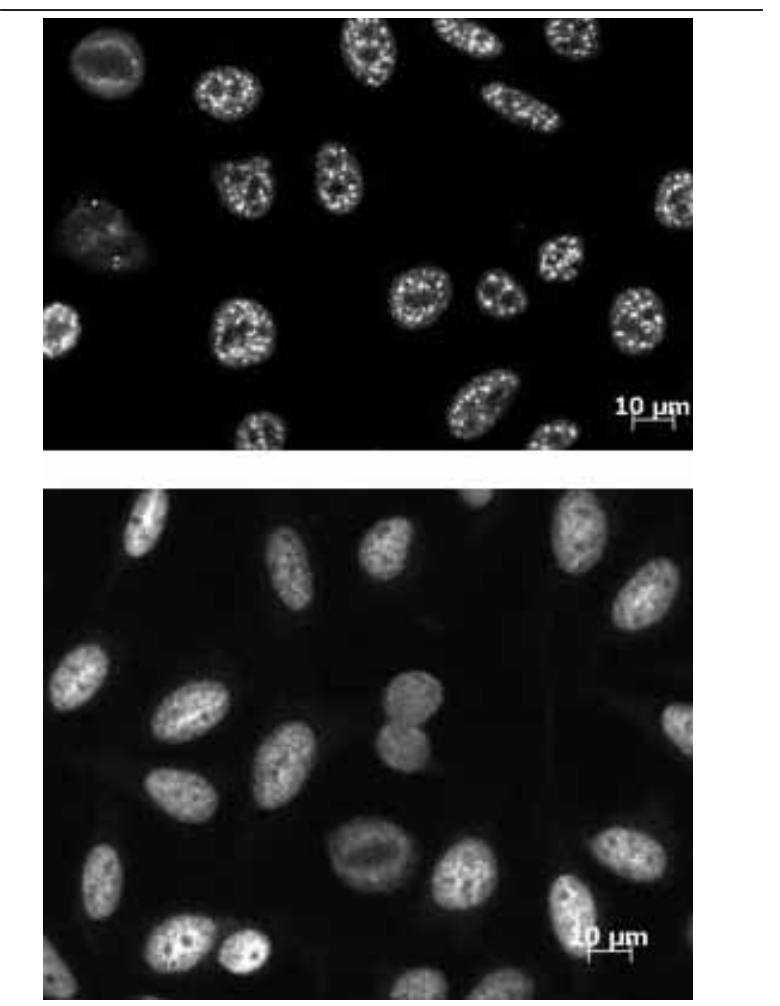

FIGURE 3 - Nuclear coarse speckledpattern in samples with anti-U1 RNP antibodies Upper panel: expected and observed pattern on slides $A-G$.

Lower panel: discrepant fine speckled pattern observed on slide $H$.

RNP: ribonucleoprotein. 

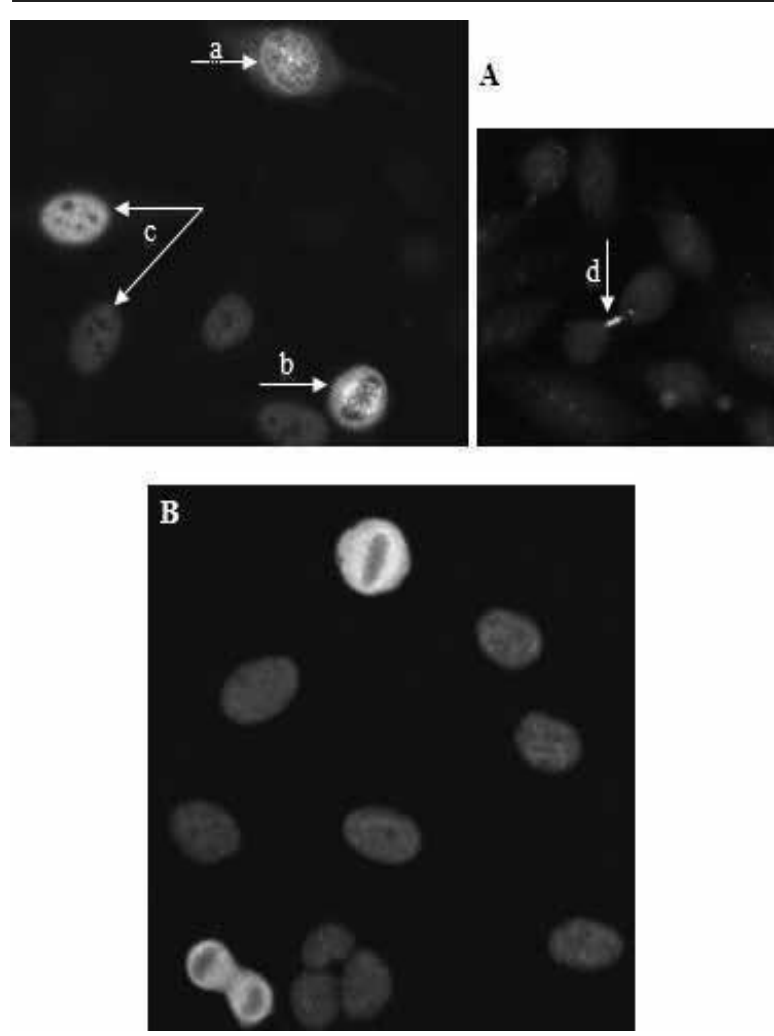

FIGURE 4 - CENP-F pattern

Upper panel: expected and observed pattern on slides A and G; arrow a: cell in prophase expressing centromeres; arrow b: furrowed chromosome plate; arrow c: cell nuclei with subtle difference in fluorescence intensity; arrow d: intercellular bridge. Lower panel: discrepant nuclear fine speckled observed in slides $B, C, D, E, F$ and $H$.

CENP-F: centromeric protein F.

To evaluate the reproducibility of cytoplasmic patterns, we used a sample with anti-Jo-1 autoantibodies, which can be visualized as a fine speckled pattern, and a sample with autoantibodies against ribosomal $P$ protein, which can be visualized as dense fine speckled pattern. The cytoplasmic fine speckled pattern was observed only in slides A and F, whereas slides $\mathrm{C}, \mathrm{G}$ and $\mathrm{H}$ exhibited nuclear fine speckled pattern. There was a negative reaction in slides B, D and E. The cytoplasmic dense fine speckled pattern was observed in all slides.

To assess the reproducibility of nucleolar patterns, we applied the following protocol: a sample with anti-PMScl autoantibodies, which could be visualized as nuclear fine speckled and homogeneous nucleolar patterns; a sample with anti-fibrillarin autoantibodies, which could be identified as nucleolar clumpy pattern; a sample with a pattern suggestive of the presence of antiRNA polymerase 1. Nucleolar patterns were recognized in all slides.

NuMA and NuMA-1-2 patterns, associated with the mitotic apparatus, were not detected in any of the slides. In slide $\mathrm{H}$,
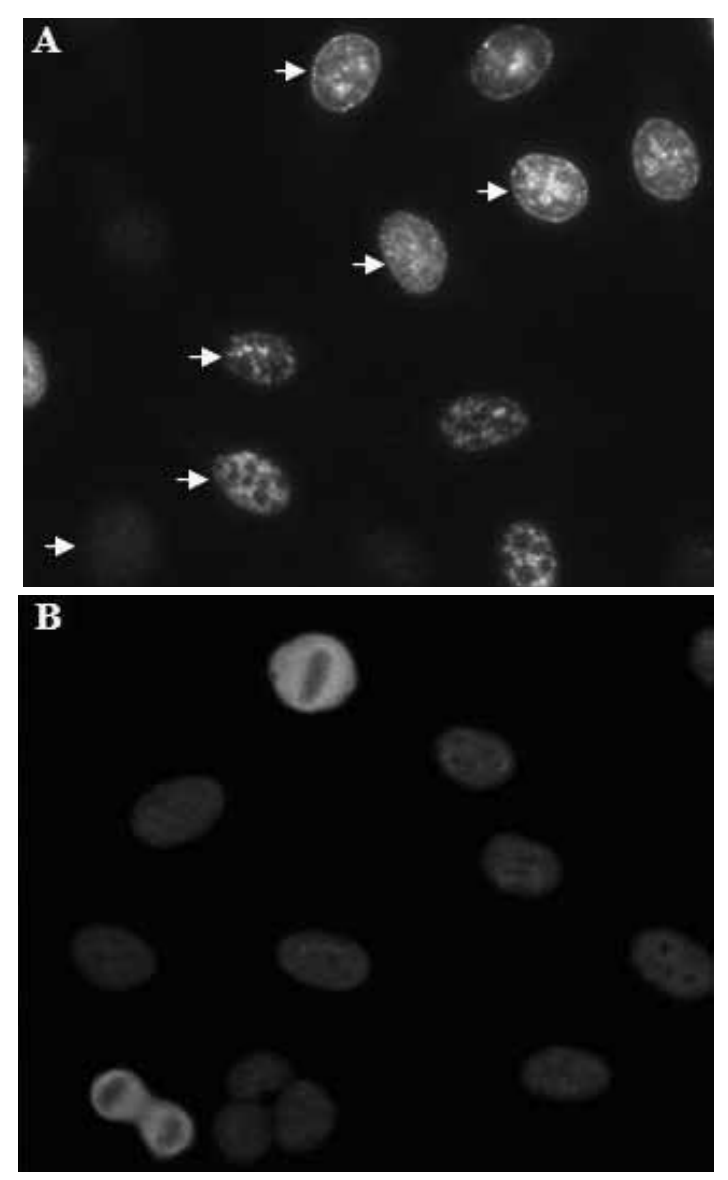

FIGURE 5 - PCNA pattern

Upper panel: expected and observed pattern in slides $A$ and $D$. The arrows indicate characteristic pleomorphism of the visualized pattern when there is presence of antibodies against cell proliferation antigen.

Lower panel: discrepant nuclear fine speckled observed in slides B, C, E, F, G and $H$. PCNA: proliferating cell nuclear antigen

NuMA-1 was observed only as a speckled nuclear pattern and NuMA-2 presented weak reaction and low definition (Figure 6A and $\mathbf{B})$.

\section{DISCUSSION}

IIF test with HEp-2 cells as antigen substrate is currently the gold standard for the detection of autoantibodies against cellular antigens (ANA-HEp2) ${ }^{(21)}$. The yielded results indicate the relative serum levels (titer) and probable antigenic associations (immunofluorescence pattern) of autoantibodies present in the sample $^{(10,11)}$. Thus, the test valuation and interpretation were based on the previous information. For example, the homogeneous nuclear pattern suggests the presence of autoantibodies against native DNA and/or nucleosome, which are considered SLE 


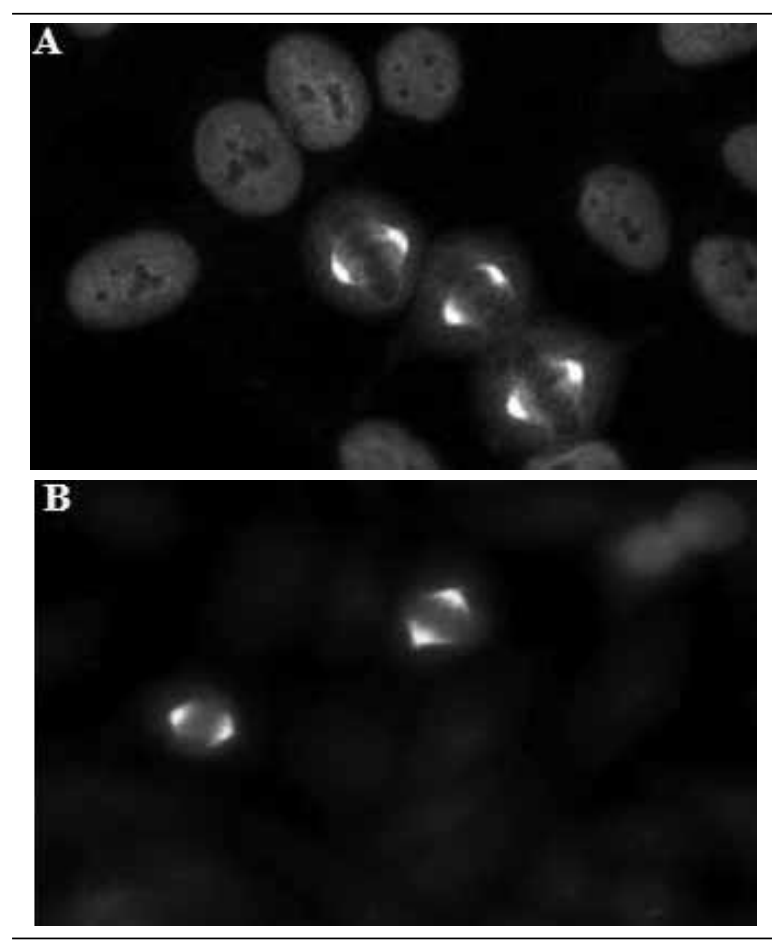

FIGURE $\mathbf{6}$ - NuMA-1 and NuMA-2 patterns

Upper panel: expected NuMA-2 observed in slides A to $G$.

Lower panel: expected NuMA-2 pattern identified in slides A to G.

NuMA-1; nuclear mitotic apparatus protein 1; NuMA-2: nuclear mitotic apparatus protein 2.

markers ${ }^{(19)}$, whereas the dense fine speckled pattern demonstrates the presence of anti-LEDGF/p75 antibodies, which have no specific relation with systemic autoimmune disease and are commonly found in healthy individuals ${ }^{(11)}$. The same considerations apply to other standards: nuclear speckled, commonly associated with the presence of anti-Sm, which is a SLE marker ${ }^{(15)}$; anti-U1 RNP, which is found in SLE, mixed connective tissue disease and systemic sclerosis; coarse speckled type reticulated associated with small ribonucleoproteins and even in high titers is rarely associated with a specific autoimmune disease ${ }^{(11)}$.

Accordingly, different commercial brands of HEp-2 slides may have impact on the accurate identification of IIF pattern in ANA-2-HEp-2 assay, from which practical implications arise, inasmuch as the inaccuracy of a given antigen expression may lead to misinterpretations (Figure 1). Considering that the expression and topographical distribution of autoantigens is under direct influence of HEp-2 fixation method, it is possible that some IIF patterns are not adequately expressed due to the way that the antigenic substrate ${ }^{(18,20)}$ was prepared. The diversity of commercial kits in the international and nationals markets has given rise to this study. Moreover, uncontrolled experiments at laboratories specialized in autoimmunity have substantiated different immunofluorescence patterns in different slide brands (Figures 3 to 6 ), which may result in differences in results between laboratories and ultimate clinical consequences.

Some inconsistent results between slides corroborate the literature, insofar as some target antigens are more susceptible to damages resulting from the fixation protocols and cell culture handling ${ }^{(8,18,20)}$. The cytoplasmic speckled pattern associated with anti-Jo-1, for example, is not always observed, and this is an anticipated fact, because the target antigen of these autoantibodies is not always preserved in this type of substrate. The appropriate indication of antibody presence has direct clinical application due to the fact that it is a myositis marker. Therefore, whenever there is clinical suspicion of its presence, specific tests such as double immunodiffusion are recommended, given the unreliability of ANA-HEp-2 test in this case. The same is expected in the identification of PCNA pattern as the target antigen is extremely sensitive to handling. It is also known that SS-A/Ro antigen may not be present in some HEp-2 cell preparations.

According to the literature, except for these fragile antigens, the concordance observed among the evaluated substrates was unexpected. The present study showed a favorable scenario in which most patterns were suitably detected in most antigenic substrates. This result is possibly related to the fact that the samples were selected because of their unique IIF patterns in representative medium/high titers. It is reasonable to assume that reproducibility may be lower when test samples are associated with less clear and mixed patterns. Nevertheless, it is worth highlighting that we observed inaccurate identification of some patterns in some substrates. For example, the nuclear speckled pattern resulting from the presence of autoantibodies against U1RNP was not identified in slide $\mathrm{H}$. The same result was observed in patterns associated with mitotic spindle components (NuMA-1 and NuMA-2). This demonstrates the paramount need to use a panel of control samples for the validation of batches and HEp-2 cell brands used in ANA-HEp-2 tests. It is particularly worth mentioning that laboratories require more than one commercial substrate for occasional result confirmation (Figure 1). In addition, they need to maintain collections of positive samples that allow to assess continually the reproducibility of different kits in the identification of various patterns.

The differences among the participants' interpretations reveal the need for continued education and training in order to ensure the appropriate identification of the surveyed patterns (Figure 2). Thus, it is important to highlight the major role of different groups worldwide attempting to standardize ANA-HEp-2 test. Brazil is a pioneer in this initiative with the establishment of the National Consensus for autoantibody research on 
HEp- $2^{(2)}$, followed by groups from Germany ${ }^{(16)}$, France ${ }^{(15)}$, Denmark $^{(21)}$ and Argentina ${ }^{(1)}$.

Not only does this investigation demonstrate how the seventeen ANA-HEp-2 patterns on substrates from eight different origins were identified, but it also recommends that laboratories should use sample collections and include different cellular antigens whenever there is a change in HEp-2 slide batches or commercial brand.

\section{ACKNOWLEDGMENTS}

To Amandia Cristina Camilo Pinto and Louise Seselgis Tendler from Fleury Immunology Department for their important role in the preparation of images.

To the suppliers who kindly agreed to participate in this assessment and provided the required materials.

\section{RESUMO}

Introdução: A imunofluorescência indireta (IFI) utilizando células HEp-2 como substrato antigênico é o teste padrão-ouro para a pesquisa de autoanticorpos contra antígenos celulares. Contudo, as condições de cultivo, fixação e permeabilização celular interferem diretamente na preservação e na distribuição espacial dos antígenos. Portanto, pode-se presumir que distintas condições no preparo das células possam interferir no reconhecimento dos padrões de imunofluorescência associados aos diversos autoanticorpos. Objetivo: Avaliar um painel de amostras de soro representativo de padrões nuclear, nucleolar, citoplasmático, de aparelho mitótico e de placa cromossômica em substratos de células HEp-2 de diferentes fornecedores. Materiais e métodos: Sete observadores blindados e independentes de três centros de referência avaliaram 17 amostras que apresentavam diferentes padrões nucleares, nucleolares, citoplasmáticos e associados ao aparelho mitótico em lâminas com células HEp-2 de oito procedências. As lâminas foram codificadas para manter a confidencialidade das marcas, bem como dos centros participantes. Resultados: Os 17 padrões de imunofluorescência em células HEp-2 foram reconbecidos na maioria dos substratos. No entanto, alguns substratos mostraram déficit na apresentação de alguns padrões (nuclear pontilhado grosso/U1-ribonucleoprotein associado a anticorpos contra o RNP (U1 ribonucleoproteína), sugestivo da presença de anticorpos anti-CENP-F (proteina centromérica F), sugestivo de anticorpos contra antígenos de célula em proliferação (proliferating cell nuclear antigen [PCNA]), citoplasmático pontilhado fino associado a anticorpos anti-Jo-1 (histidil sintetase), anti-NuMA-1 (nuclear mitotic apparatus protein 1) e anti-NuMA-2 (nuclear mitotic apparatus protein 2). Conclusão: Em que pese a boa qualidade geral dos substratos avaliados, existe divergência nos resultados obtidos entre os diferentes substratos comerciais. As variações observadas podem ser devidas aos lotes avaliados, portanto não se pode generalizar para as respectivas marcas. Recomenda-se que cada novo lote ou marca de lâmina sejam testados com diferentes soros referência representativos dos diversos padrões.

Unitermos: anticorpos antinúcleo; fator antinúcleo; autoanticorpos; padrões de imunofluorescência; imunofluorescência indireta.

\section{REFERENCES}

1. CARBallo, 0. G. et al. Primer consenso argentino para la estandarización de la determinación de anticuerpos anti-nucleares por inmunofluorescencia indirecta-HEp-2. Acta Bioquim Clin Latinoam, v. 46, n. 1, p. 3-14, 2012.

2. DELlaVANCE, A. et al. $3^{\circ}$ Consenso brasileiro para pesquisa de autoanticorpos em células HEp-2 (FAN). Recomendações para padronização do ensaio de pesquisa de autoanticorpos em células HEp-2, controle de qualidade e associações clínicas. Rev Bras Reumatol, v. 49, n. 2, p. 89-109, 2009.

3. DELLAVANCE, A. et al. Consenso nacional para padronização dos laudos de FAN HEp-2.J Bras Patot Med Lab, v. 38, n. 3, p. 201-16, 2002.

4. DELLaVANCE, A. et al. Redefining the Scl-70 indirect immunofluorescence pattern: autoantibodies to DNA topoisomerase I yield a specific compound immunofluorescence pattern. Rheumatology (Oxford, England), v. 48, n. 6, p. 632-7, 2009.

5. DELLAVANCE, A.; ANDRADE, L. E. C. Como interpretar e valorizar adequadamente o teste de anticorpos antinúcleo.J Bras Patol Med Lab, v. 43, n. 3, p. 157-68, 2007.

6. FRITZLER, M. J.; KINSELLA, T. D. The CREST syndrome: a distinct serologic entity with anticentromere antibodies. Am J Med, v. 69, n. 4 , p. 520-6, 1980.

7. FRITZLER, M. J. et al. The use and abuse of commercial kits used to detect autoantibodies. Arthritis Res Ther, v. 5, n. 4, p. 192-201, 2003.

8. GUILLOT, P. V. et al. Fixation-induced redistribution of hyperphosphorylated RNA polymerase II in the nucleus of human cells. Exp Cell Res, v. 295, n. 2, p. 460-8, 2004. 
9. HADDOUK, S.; MARZOUK, S.; JALLOULI, M. et al. Clinical and diagnostic value of ribosomal $P$ autoantibodies in systemic lupus erythematosus. Rheumatology (Oxford, England), v. 48, n. 8, p. 953-7, 2009.

10. KUMAR, Y.; BHATIA, A.; MINZ, R. W. Antinuclear antibodies and their detection methods in diagnosis of connective tissue diseases: a journey revisited. Diagn Pathol, v. 4, p. 1, 2009.

11. MARIZ, H. A. et al. Pattern on the antinuclear antibody-HEp-2 test is a critical parameter for discriminating antinuclear antibody-positive healthy individuals and patients with autoimmune rheumatic diseases. Arthritis Rheum, v. 63, n. 1, p. 191-200, 2011.

12. MASI, A. T. R. G. et al. Preliminary criteria for the classification of systemic sclerosis (scleroderma). Bull Rheum Dis, v. 31, n. 1, p. 1-6, 1981.

13. MERONI, P. L.; SCHUR, P. H. ANA screening: an old test with new recommendations. Ann Rheum Dis, v. 69, n. 8, p. 1420-2, 2010.

14. MIGLIORINI, P. et al. Anti-Sm and anti-RNP antibodies. Autoimmunity, v. 38, n. 1, p. 47-54, 2005.
15. PHAM, B. N. et al. Impact of external quality assessment on antinuclear antibody detection performance. Lupus, v. 14, p. 113-9, 2005.

16.SACK,U.etal.Autoantibodydetection using indirectimmunofluorescence on HEp-2 cells. Ann N Y Acad Sci, v. 1173, p. 166-73, 2009.

17. SATOH, M. et al. Prevalence and sociodemographic correlates of antinuclear antibodies in the United States. Artbritis Rheum, v. 64, n. 7, p. 2319-27, 2012.

18. STADLER, C. et al. A single fixation protocol for proteome-wide immunofluorescence localization studies. J Proteomics, v. 73, n. 6 , p. 1067-78, 2010.

19. TAN, E. M. et al. The 1982 revised criteria for the classification of systemic lupus erythematosus. Arthritis Rheum, v. 25, n. 11, p. 1271-7, 1982.

20. TSIAKALOU, V. et al. Optimized detection of circulating anti-nuclear envelope autoantibodies by immunofluorescence. BMC Immunol, v. 7 , p. 20, 2006.

21. WIIK, A. S. et al. Antinuclear antibodies: a contemporary nomenclature using HEp-2 cells. J Autoimmunity, v. 35, n. 3, p. 276-90, 2010.

\section{MAILING ADDRESS}

